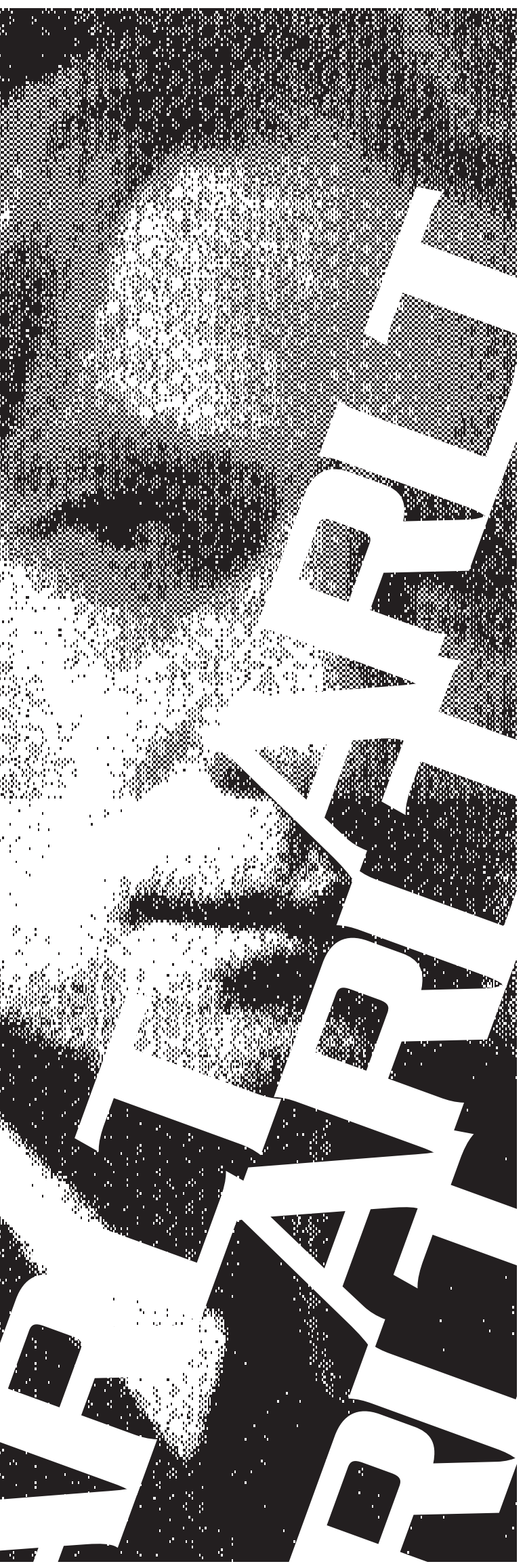

\title{
Roberto Arlt:
}

a experiência

radical

\section{da escritura}

MARÍA ZULMA

M. KULIKOWISKI

é professora de Língua

Espanhola do

Departamento de Letras

Modernas da FFLCH-USP e

autora de Seria Cômico se

não Fosse Trágico: 0

Discurso Grotesco de

Roberto Arlt (Tese de Doutorado, FFLCH-USP). 


\section{a LÍNGUA ALHEIA, A LÍNGUA ALIENADA}

* Editado no Brasil sob o título de As Feras, trad. de Sergio Molina, São Paulo, Iluminuras, 1996 (N.T.).

Sob esses nomes que correspondem ao bairro portenho de Boedo e à rua Florida de Buenos Aires, conhecem-se duas correntes literárias que tiveram posições divergentes. Os escritores de Boedo, agrupados no início na revista Claridad, eram defensores da literatura como arma de luta e redenção, buscavam retratar os problemas sociais a partir do realismo. Os do grupo Florida agrupados na revista Martín Fierro, proclamavam a neces sidade de uma verdadeira revolução estética com uma visão cosmopolita.

2 Ricardo Piglia considera que a literatura argentina deve ser lida a partir de Arlte não de Borges, a quem considera um escritor do século XIX. Entrevista de Ricardo Piglia a Héctor Alimonda, "Sobre Falsificações e Outras Histórias", in Novos Estudos Cebrap, no 23, São Paulo, março de 1989.

$3 \bigcirc$ autor se dedicou a alguns inventos, como o de fabricar meias femininas que não rasgassem, e outras experiências químicas. Seus personagens também são inventores: Silvio de O Brinquedo Raivoso, fabrica um contador automático de estrelas fugazes, Erdosain inventou, com os Espila, a rosa de cobre, etc., em Os Sete Loucos e Os Lança-chamas aparecem inclusive ilustrações das máquinas que alguns dos persona gens inventavam, e a Sociedade Secreta se caracteriza po ter planos de fabricar armas mortíferas e gases venenosos.

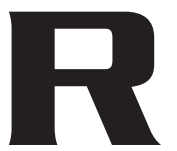

oberto Arlt (1900-42) foi para

a literatura argentina - e tal-

vez seja até hoje-uma figura incômoda, porque nunca foi unanimidade, porque nele não convergem tradições literárias, linhas estéticas, pensamentos nem ideologias. Em Arlt tudo é divergente e dissonante. Sua obra e sua própria figura de escritor fogem às regras e à facilidade das dicotomias.

A publicação de seu primeiro romance, O Brinquedo Raivoso, em 1926, significou o início da narrativa urbana na literatura argentina cujo centro, Buenos Aires, entrava na literatura como a fratura de uma visão idealizante e homogênea do espaço nacional. Suas obras posteriores, Os Sete Loucos (1929), Os Lança-chamas (1931), O Amor Bruxo (1933), seu livro de contos OCorcundinha* (1933), e posteriormente sua produção teatral assinalaram o começo de uma escritura marcada pela quebra dos cânones estabelecidos.

As perguntas sobre se Arlt pertenceu efetivamente a Boedo ou a Florida (1), se sua ideologia respondia aos princípios da direita ou da esquerda, se pode ser considerado um escritor realista, expressionista ou fantástico, vão criando idas e vindas nessa necessidade de contar entre suas fileiras em algum momento com este escritor filho de imigrantes, rebelde e polêmico. No entanto, a obra arltiana, original e deslumbrante, consegue fugir dos rótulos e hoje se nos apresenta como um lugar privilegiado para se ler, nela, os processos de construção de uma escritura inaugural a partir da qual, segundo Ricardo Piglia (2), deve-se ler a literatura argentina.
"Sempre pensei que esse homem que tratava de expressar-se numa língua da qual só conhecia seu maior poema era uma metáfora perfeita da máquina de Macedonio. Contar com palavras perdidas a história de todos, narrar numa língua estrangeira" (Ricardo Piglia, $A$ Cidade Ausente).

Roberto Arlt não inventou uma língua, ainda que gostasse de ter feito, ele que foi um inventor de impossíveis, como muitos de seus personagens (3). Bem sabia Arlt o difícil que era trabalhar com uma materialidade lingüística que sentia artificial na rebuscada poesia modernista (4), encastelada em rígidos cânones estéticos que eram também limites demarcatórios de gosto, classe social e poder político. Possuir uma língua escrita, dominá-la em sua complexidade, era uma arma de poder da qual estavam excluídos a grande maioria dos argentinos e sobretudo os imigrantes que compunham mais de dois terços dos habitantes dessa cidade babélica que era Buenos Aires. Como afirma Angel Rama (5) a palavra escrita na América Latina vivia “como a única verdadeira, possuía rigidez e permanência, um modo autônomo que arremedava a eternidade. Estava livre das vicissitudes e metamorfoses da história mas, sobretudo, consolidava a ordem por sua capacidade para expressá-lo rigorosamente em nível cultural". Junto com a língua, o domínio dos imaginários culturais e simbólicos nela sedimentados pertencia a uma minoria excludente, cuja representação de língua passava longe da sociedade, onde os referentes eram outros. A distância entre a oralidade e a escritura alcançava, no início do século, talvez seu maior grau, tanto pela aparição da literatura gauchesca (6) como pela singularidade das mesclas lingüísticas que a imigração aportava. Sobre esse primeiro discurso ordenado, proporcionado pela regularidade normatizada da 
língua, articulava-se um segundo, que era proporcionado pela chegada dessa massa imigratória e pelo crescimento das cidades. Nesse momento da história argentina, de grande instabilidade lingüística, Roberto Arlt, sem possibilidade de escolher uma língua, de ler numa língua estrangeira e, portanto, condenado a ler traduções, tem que trabalhar uma variante "empobrecida" como o espanhol rioplatense, escreve tentando, em vão, colocar entre aspas, de maneira irregular, o cocoliche (7), o lunfardo (8), para deixar escutar sua própria voz. Sua luta com a língua espanhola é, como o diz claramente em várias de suas Aguafuertes Porteñas, uma luta com uma língua em transformação, contra o palavrório sem sentido dos escritores que se crêem como tais "embora não sejam lidos nem por seus familiares"; contra o dever ser e o "deve-se dizer assim", contra a afetação e os eufemismos, contra o círculo asfixiante da cultura oficial. Desafiando os puristas que se perguntavam "onde nossa língua vai parar?” Arlt respondia: "Ora, na formação de um idioma sonoro, flexível, flamante compreensível para todos, vivo, nervoso, colorido por estranhos matizes e que substituirá um rígido idioma que não corresponde à nossa psicologia. Porque eu acredito que a linguagem é como uma roupa. Há raças em quem não cai bem determinado idioma; outras, em compensação, têm que modificá-lo, rasurá-lo, aumentá-lo, poli-lo, desglosar estruturas, inventar substantivos..." (“Onde Nossa Língua Vai Parar?", Aguafuertes Porteñas.)

Como observa Theodor Adorno (1983, p. 26), "a espiritualização das obras de arte incitou o rancor dos excluídos da cultura”. Arlt era um deles. Num momento de luta pela apropriação dos sentidos, do poder simbólico, das palavras, Arlt luta para disputar um espaço escritural e questionar o considerado belo, o gozo estético que produz a espiritualização da chamada literatura "alta".

Roberto Arlt se introduz não só no terreno inexplorado do novo, como procura enunciar a partir de uma realidade que se nomeia de outro modo. Penetra no territó- rio do nunca dito antes, do insuportável, verbaliza o que a sociedade queria ocultar. A temática da ficção arltiana desafia o sistema de valores sociais estabelecidos e incorpora em sua temática a traição como meio de redenção, a loucura, o suicídio, o homossexualismo e a prostituição. Exibe esses "não-valores" com um desafiante repertório lingüístico que transforma tanto seus romances como suas crônicas num discurso do escândalo. À margem dos cânones e a partir de procedimentos experimentais, usa as palavras de maneira irreverente: hiperboliza, oximoriza, ridiculariza, parodia, muda de lugar, superpõe, passa de uma formação discursiva para outra, de um registro para outro, e consegue efeitos cômicos, ofensivos, grotescos, transgressores.

Arlt podia fazê-lo porque não tinha compromissos com escolas nem correntes. Esse escritor irreverente não possuía uma tradição literária - como Borges ou Güiraldes, seus contemporâneos - com a qual criar uma intertextualidade ou uma erudição à qual sua obra daria continuidade. Como observam muitos críticos, inclusive o próprio Julio Cortázar no prólogo a suas Obras Completas, Arlt não teve nem “uma biblioteca minimamente equipada [...] teve que abrir caminho frente a si mesmo com dificuldades instrumentais que outros haviam superado rapidamente graças aos seletos colégios e os respaldos familiares". Se isso contou sempre como uma desvantagem para Arlt, permitiu-lhe também invadir as fronteiras que separam o "bom gosto", "o belo", "o elevado", superar os significados criados pela convenção e o senso comum, escrevendo "em orgulhosa solidão livros que sejam como um cross na mandíbula" (prólogo de Os Lança-chamas). Hoje constatamos que esse "não saber escrever" atribuído a Arlt durante décadas foi produto de uma busca deliberada por parte do escritor da renovação de seu próprio instrumento expressivo, a linguagem.

Por isso, pode-se ler em sua obra uma reveladora auto-referencialidade literária. Constatamos, sob a ótica da heterogeneidade discursiva (9), que é possível ler
4 modernismo hispano-americano, de caráter marcadamente esteticista, teve grande importância na renovação da lírica em língua espanhola, sobretudo a partir da obra do nicaragüense Rubén Darío. Leopoldo Lugones proclamou na Argentina a "aristocracia intelectual da arte" e colocou a literatura e a cultura clássica como modelo a ser seguido.

5 La Ciudad Letrada Montevideo, Comisión Uruguaya pro Fundación Ángel Rama, 1984, p. 17

6 A gauchesca incorpora a linguagem dos "gauchos", habitantes do pampa argentino, e sua obra mais importante é Martín Fierro, de José Hernández, considerado o grande épico nacional. Foi uma obra que teve grande repercussão e nela se destaca a reconstrucão da oralidade do homem do interior

7 cocoliche é uma interlíngua utilizada pelos italianos chegados como imigrantes e que tentavam comunicar-se em espa nhol. Segundo María Beatriz Fontanela de Weinberg "o cocoliche foi o resultado da proximidade de ambas as línguas, mas resolveu-se rapidamente já que os netos de imigrantes italianos foram monolíngües em espanhol" $|E|$ Español Bonaerense. Cuatro Siglos de Evolución Lingüística, Buenos Aires, Hachette, 1987 pp. 138-43)

8 O lunfardo é a gíria de Buenos Aires.

9 Os conceitos de heterogeneidade estão baseados em Jaqueline Athier, "Hétérogénéité Montrée e Hétérogénéité Constitutive: Éleménts pour une Approche de Láutre dans le Discours", in DRLAV, 26, 1982, pp. 91-151. 
na narrativa arltiana seu próprio processo de criação. No romance $O$ Brinquedo Raivoso o narrador em primeira pessoa cria um EU que conta a história de sua infância e sua iniciação simultânea no mundo dos adultos e no mundo dos livros. À medida que cita suas leituras - o folhetim, a poesia de Baudelaire, os textos técnico-científi$\cos -\mathrm{o}$ narrador as exibe e imediatamente se apropria delas. Essas cenas ficam evidentes especialmente no momento em que o personagem se prepara para realizar "ritos de iniciação" (como leitor de folhetins, como ladrão de uma biblioteca, como aspirante a um emprego na Escola Militar de Aviação), exibe um "engendramento discursivo" que incorpora as ofertas de leitura que tinha à disposição.

Em O Brinquedo Raivoso, na famosa cena do assalto à biblioteca por parte de Silvio e seus amigos, o personagem conta a Enrique que terminou com sua noiva Eleonora e que "eu sentia vontade de chorar... e não nos dizíamos nada... O que é que íamos nos dizer?"'(10). Pouco depois, Silvio encontra um livro de Baudelaire, lê um poema em voz alta:

“Eu te adoro do mesmo modo que a abóboda [noturna. Oh! Copo de tristeza! Oh! Branca taciturna.

Eleonora - pensei - Eleonora

Evamos aos assaltos, vamos, como diante de um cadáver, um coro de ciganos" (11).

Desta forma, numa clara apropriação, Arlt lança mão de procedimentos de amostragem, exibe sua rede discursiva e, a partir do que Athier (12) define como heterogeneidade discursiva mostrada, mostra as para formular a instância da enunciação, de acordo com 0 proposto por D. Maingueneau (1993, p. 32) para enfatizar preeminência e preexistência da topografia social, onde se inscrevem os enunciadores. lava sob a forma de revistas, junto a expressões da picaresca espanhola e do romantismo tardio.

Mas se, como dizíamos, Arlt não pôde criar outra língua que servisse para expressar esse país em formação-sonho também de Sarmiento no século XIX -, inaugura um novo uso da linguagem, produz uma intervenção nos cânones estético-literários vigentes na Argentina de princípios do século XX. Transforma a língua no cenário das contradições, desmascara o falso e o alheio, inaugura estratégias discursivas e ficcionais, incorporando à literatura argentina, tão propensa a reproduzir os modelos europeus, novas vozes, novas falas, novos discursos, produtos de um hibridismo social que estava ocorrendo diante de seus olhos, e, sobretudo, uma nova maneira de dizer. E esse entrecruzamento inusitado de vozes e discursos teve como resultado uma obra que está mostrando uma experiência de linguagem capaz de exibir em si mesma as estratégias de sua própria construção.

\section{AS ARMADILHAS DO REAL}

\footnotetext{
“Um relato estranhíssimo. A história de um homem que não tem palavras para nomear o horror. Alguns dizem que é falso, outros dizem que é a pura verdade. Os tons da fala, um documento duro, que vem da realidade" (Ricardo Piglia, A Cidade Ausente).
}

Dizíamos que na obra de Arlt surgem novas operações lingüísticas destinadas a dar conta dessa comoção referencial produzida pela desestabilização da relação entre o sentido e sua referência. As representações de mundo, tempo e espaço que conformam o imaginário social dentro do qual se articulam as concepções de realidade e de conhecimento vêem-se sacudidas pela transformação acelerada da sociedade e da cultura argentina em virtude da chegada dos imigrantes com suas tradições e culturas. Podese ler esta comoção em diferentes recortes da produção literária da época, especialmente 
nas crônicas e no teatro.

Na obra de Arlt existe uma dupla tensão: a de trabalhar essas novas realidades e a de criar uma "realidade ficcional" que se nomeia de outro modo. Realiza uma renomeação do mundo referido capaz de criar uma rede de novas significações que dêem conta desse espaço ficcional. Arlt poderia ter se conformado com meras anotações realistas de cunho descritivo tentando, no detalhe, dar ao discurso ficcional uma cor local, como inúmeras obras de costumes o faziam, incorporando as falas que tipificavam os recém-chegados, pela imitação ou a paródia. No entanto, Arlt foge da verossimilhança simplificadora, tem consciência de que as produções discursivas não podem ser uma analogia da realidade e sim que recortam, a seu modo, o universo referencial, impõem uma forma particular à substância do conteúdo para criar uma ilusão de realidade que "sai do mundo empírico e cria outro mundo com essência própria e contraposto ao primeiro, como se este novo mundo tivesse consistência ontológica" (Adorno, op. cit., p. 39). Dessa forma, aposta num novo leitor, capaz de reconhecer e de se reconhecer nesse universo ficcional, de decodificar no complexo processo de leitura esses novos procedimentos expressivos que incluem desde os registros escatológicos até as obscenidades raivosas e desafiantes, passando pela desmesura de suas hipérboles e pelos surpreendentes e inusitados oximórons.

Em seu primeiro romance, $O$ Brinquedo Raivoso, encontramos uma verdadeira apresentação pictórica da paisagem urbana e dos personagens como o Sapateiro Andaluz, Dío Fetente, don Gaetano e sua terrível mulher e outros imigrantes que convivem com os personagens da literatura folhetinesca, que ele incorpora e atualiza. Um narrador em primeira pessoa, o adolescente Silvio, adota um ponto de vista de observador rigoroso, a partir do qual organiza enunciados para outorgar veracidade às descrições - continuamente o narrador se preocupa em pontuar que são “como os cromos...", ou seja, vai fazendo uso de um sistema de referências reconhecíveis e identificáveis, um aparente registro neutro do real que organiza essa realidade como nova.

"Decoravam a frente da espelunca capas de cadernos que narravam as aventuras de Montbars, o Pirata e de Wenongo, o Moicano. Nós, os garotos, ao sair da escola, nos deleitávamos observando os cromos que ficavam pendurados na porta, descoloridos pelo sol" (14).

"O lugar do reencontro era sempre os fundos de um encanador, certo cromo de Cacaseno com cara de lua, crescido em

14 El Juguete Rabioso, in Roberto Arlt-Obra Completa, Buenos Aires, Carlos Lohlé, tomol p. 11.

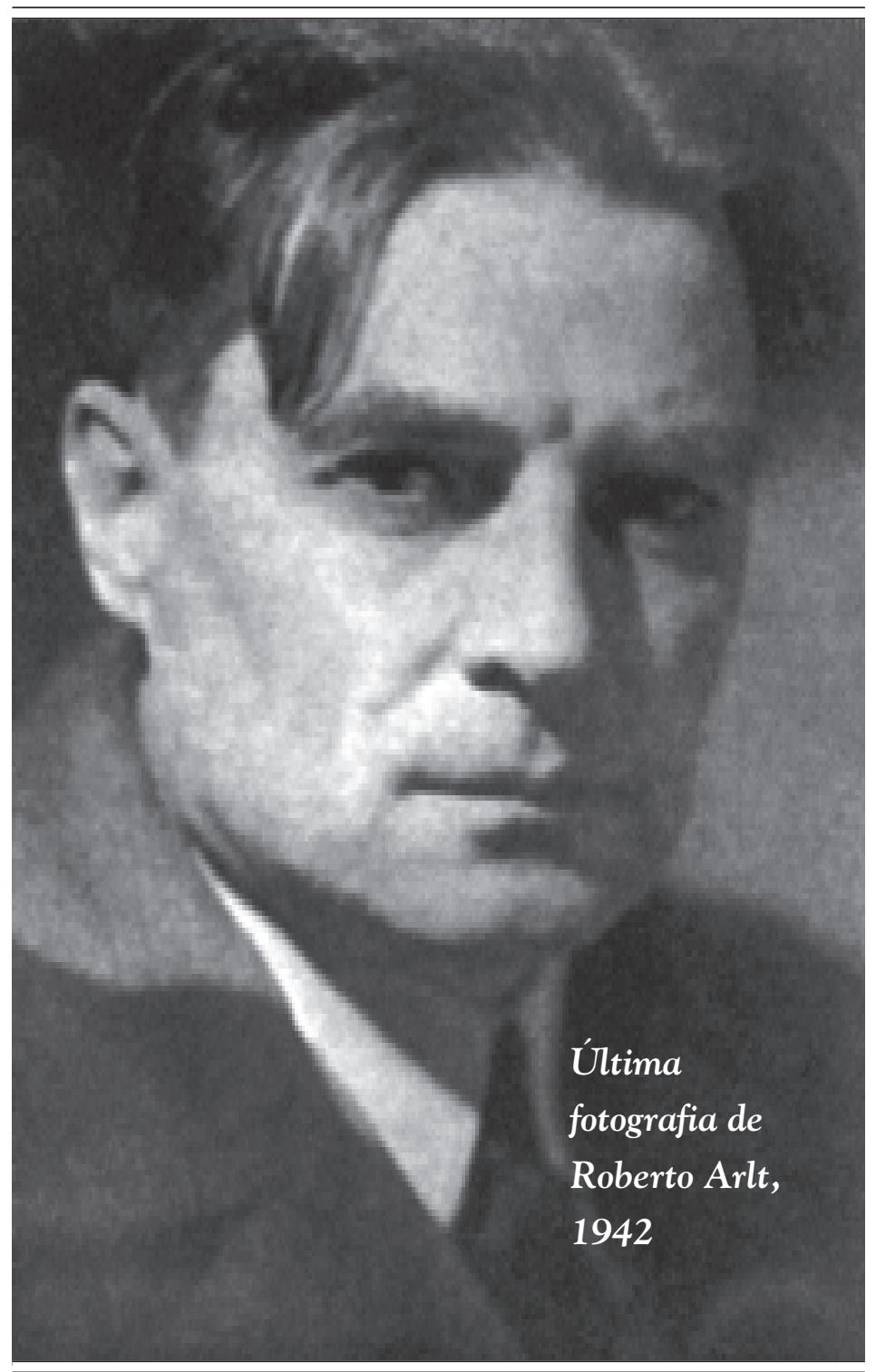


anos, ventre e cornos, porque sabia-se que tolerava com paciência” (15).

“E eu, eu, senhor, não terei nunca uma querida tão linda como essa querida que luzem os cromos dos livros viciosos!" (16).

No entanto, Arlt realiza uma operação sobre esses mesmos enunciados que vão criando um distanciamento entre o que é dito e o que o enunciador pretende que seja entendido ou interpretado, desautorizando a palavra monossêmica e quebrantando a fé no poder da ilusão mimética. Nessa primeira obra, junto à diagramação de uma cidade e seus habitantes, há marcas do grotesco como um recurso estruturador dos personagens, tanto na descrição dessas figuras como exageradas, hiperbólicas, como nos efeitos de sentido que elas produzem, chegando a ser estranhas, cômicas, trágicas, metaforizando o olhar entre curioso e apreensivo ante esse "outro" recém-chegado de quem pouco se sabe ou se entende. A primazia do corporal, de uma figura que deve necessariamente construir-se a partir da linguagem, permite uma dupla leitura pois a incorporação de um elemento que, contrapondo-se ao repertório simbólico do belo e do conhecido, incorpora o deformado e o grotesco, como são os personagens de O Brinquedo Raivoso, seres sem passado e sem história, serve de testemunho perturbador onde a alteração de proporções e de elementos contraditórios, a proliferação e disseminação do híbrido, produzem uma representação do mundo incompreensível, inquietante.

Essa visão se radicalizará em seus romances seguintes -Os Sete Loucos e Os Lança-chamas -, com a criação de uma Sociedade Secreta alegoricamente reduzida a uma reunião de loucos, militares, fascistas, comunistas, místicos, ladrões e prostitutas, que produzem discursos contraditórios que ninguém escuta e nos quais nem

15 ldem, ibidem, p. 18.

$16 \mathrm{ldem}$, ibidem, p. 59.

17 Los Lanzallamas, in Roberto Arlt. - Obra Completa, op. cit., tomo I, p. 470 .

18 Idem, ibidem, p. 475 eles acreditam. Na Sociedade Secreta há uma ordem simbólica representada pela desordem e a degradação.

Nestes dois romances, Arlt deixa de lado a pretensão de retratar, como fazia em $O$
Brinquedo Raivoso, e parece deixar de acreditar na capacidade das palavras de darconta desse mundo. Em Os Sete Loucos/Os Lança-chamas, as fronteiras corporais se desvanecem, "Erdosain deixa-se cair aniquilado na cama e fecha os olhos. Sua alma tem sono [...] Perde a sensação do limite de seus membros, e lhe parece que se dissolve numa neblina cujo centro sensível é seu cérebro. Dissolveu-se no mundo"(17).

A geografia da cidade se desrealiza e, embora a primeira Buenos Aires, da aventura e do desejo, esteja na outra percorrida obsessivamente por Erdosain, já é o produto de um olhar próprio do cético, que parece ter renunciado ao compromisso com a referencialidade e com a descrição. A cidade torna-se densa, desdobra-se em planos que o narrador descreve a partir do estado de ânimo dos personagens, transborda e se ficcionaliza. O narrador é capaz de interferir sobre a geografia urbana, cria seus imaginários de angústia e exclusão. Produz-se uma relação de transposição e transcodificação entre o corpo e a topografia da cidade e seus habitantes a partir do olhar perturbado de Erdosain.

"Erdosain deixa-se balançar com as pálpebras bem abertas. Às vezes enfia a cabeça sob a manta, e fica encolhido como um feto em suabolsa placentária. A essa mesmahora, milhões de homens como ele estão com os joelhos se tocando e as pernas encolhidas e as mãos recolhidas sobre o peito, semelhantes a fetos em suas bolsas placentárias. Quando o sol, deixando sombras azuis nas calçadas, projetar seu resplendor dourado sobre as altas cornijas, esses fetos abandonarão suas bolsas placentárias, abrirão uma torneira, com um pedaço de sabão desengordurarão o rosto, beberão um copo de leite, sairão na porta, subirão num trem amarelo ou num ônibus verde... e assim todos os dias..." (18).

Para os personagens da Sociedade Secreta, o mundo circundante se mescla e se reinterpreta permanentemente a partir de uma Bíblia apócrifa-como nos delírios de Ergueta - segundo os projetos revolucio- 
nários do Astrólogo, de acordo com as previsões catastróficas do extermínio por explosões e guerras químicas que serão comandadas pelo Major e subvencionadas com o lucro que produzirão os prostíbulos explorados por Haffner. Equando tudo leva a explicar essa sociedade pela via da loucura, Hipólita se pergunta: “Mas a loucura existe? Ou é que se estabeleceu uma forma convencional de expressar idéias, de modo que estas possam ocultar sempre e sempre o outro mundo de dentro, que ninguém se atreve a mostrar?" (19).

O narrador não se contenta com a visão unifocal e externa de seus personagens: move o foco, desfaz as imagens, entra nos personagens fisicamente, desentranha-os, ausculta-os, esquarteja-os em pedaços que adquirem vida própria, como no impressionante trecho "Sob a Cúpula de Cimento" de Os Lança-chamas. O narrador também amplia os pontos de vista e em Os Sete Loucos/Os Lança-chamas cria uma duplicidade com outro narrador que é chamado de "comentador" e que intervém a partir das notas de rodapé analisando e interpretando a conduta dos personagens, completando os relatos do narrador, explicando fatos exteriores à história central, ampliando detalhes sobre a vida interior dos personagens e, sobretudo, disputando o saber do contado, criando dúvidas e questionando a verdade daquilo dito pelo narrador. A parece também a figura do Autor que, sob as desconcertantes "Notas do Autor", tenta convencer - ironicamente - seus leitores da distância que devem estabelecer entre ficção e realidade, pois previne sobre possíveis relações que possam estabelecer- se entre a história ficcional e os fatos históricos simultâneos à publicação de $O$ s Sete Loucos:

“Este romance foi escrito nos anos 28 e 29, editado pela editora Rosso no mês de outubro de 1929. Seria irrisório então acreditar que as manifestações do Major foram sugeridas pelo movimento revolucionário de 6 de outubro de 1930. Indubitavelmente, acaba sendo curioso que as declarações dos revolucionários de 6 de setembro coincidam com tanta exatidão com aquelas que faz o Major e cujo desenvolvimento confirmam numerosos acontecimentos ocorridos depois de 6 de setembro" (20).

Essa nova estratégia escritural inaugurada por Arlt produz um estremecimento e uma recomposição dos lugares a partir dos quais se narra e a partir de onde se lê. Podemos compreender, então, que a obra de Arlt, um exercício de desmesura e de inovação estética, não tenha sido reconhecida nem compreendida durante tanto tempo. A imagem de mau escritor o perseguiu durante muitos anos. Mas, como diz Renzi, um personagem de Respiração Artificial, romance de Ricardo Piglia (1980, p. 166): "Arlt escrevia mal: mas no sentido moral da palavra. Sua escritura é má, uma escritura perversa [...] um estilo criminoso. Faz o que não se deve, o que está mal, destrói tudo o que durante cinqüenta anos se havia entendido por escrever bem nesta descolorida República".

Essa maldade que Arlt destila em sua escritura foi o produto de uma experiência radical de luta com a língua e a criação.
191 dem, ibidem, p. 379.

200 fato histórico ao qual Arlt alude é 0 golpe militar que derrubov o presidente Hipólito Yrigoyen, cujo governo conto va com forte apoio popular.

\section{BIBLIOGRAFIA}

ADORNO, Theodor W. Teoría Estética. Trad. Fernando Riaza. Buenos Aires, Orbis, 1983.

ARLT, Roberto. Obra completa. Buenos Aires, Carlos Lohlé (2 tomos), 1981.

PIGLIA, Ricardo. Respiración Artificial. Buenos Aires, Pomaire, 1980.

"Sobre Falsificações e Outras Histórias". Entrevista de Ricardo Piglia a Héctor Alimonda, in Novos Estudos

Cebrap, no 23, São Paulo, março de 1989.

RAMA, Ángel. La Ciudad Letrada. Montevideo, Comisión Uruguaya pro Fundación Ángel Rama, 1984, p. 17. 


\section{Traduzir}

\section{Roberto Arlt}

Roberto Arlt, "¿̇Cómo Quieren que les Escriba?", in Aguafuertes Porteñas: Cultura y Política, Buenos Aires, Losada 1994 , p. 31

2 Idem, ibidem, p. 33.

3 "A Origem de Algumas Palavras do Nosso Léxico Popular", "Divertida Origem da Palavrá 'Squenun'", "O 'Espertinho'" "O ldioma dos Argentinos", "A Crônica no 231".
MARIA PAULA

GURGEL RIBEIRO

é mestranda em Língua

Espanhola e Literaturas

Espanhola e Hispano-

americana na USP e

tradutora de Os Sete

Loucos \& Os Lanca-chamas

e Viagem Terrível, de

Roberto Arlt, ambos pela

Iluminuras.

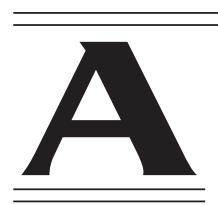

prosa desconcertante do argentino Roberto Arlt (190042) abarca vários gêneros literários: romance, crônica, conto e teatro. Em todos eles encontramos uma linguagem mordaz, ácida e de uma ironia que beira o humor negro. Sua escrita é uma mescla da linguagem das ruas com a de suas leituras de folhetins, de manuais de invenções, do dialeto dos imigrantes e de traduções espanholas de Dostoiévski, Tolstoi, em edições populares - da editora Tor - a que tinha acesso nas bibliotecas de bairro, muito comuns na Buenos Aires dos anos 20. Arlt, pode-se dizer, escrevia como lia e afirmava que "o idioma das nossas ruas, o idioma em que o senhor e eu conversamos no café, no escritório, em nosso trato íntimo é o verdadeiro" (1) e que é perfeitamente possível tratar de temas sérios utilizando essa linguagem, pois “existe algo mais importante que o idioma, e são as coisas que se dizem" (2).
O estilo de Arlt é determinado pelas condições de produção do texto: filho de imigrantes pobres, Arlt não tem o espanhol como primeira língua. É leitor de traduções numa época em que pessoas cultas ou de uma classe social mais abastada liam autores estrangeiros no original. É um estilo construído com os diversos registros e tons do seu idioma, e que vai por um caminho diametralmente oposto ao pregado pelos puristas da língua, de evitar as expressões populares, neologismos, qualquer indício da mistura e transformação lingüística produzidas pela imigração.

A mescla de registros, aliada ao fato de não ter tido uma formação sistemática, fez com que Arlt fosse constantemente criticado pela forma como escrevia. Dizia-se mesmo que ele não escrevia bem. Isso jamais o incomodou. Publicou diversas crônicas a respeito da linguagem (3), seja sobre a origem de algumas expressões populares, seja rechaçando, pura e simplesmente, aqueles que seguem estritamente as regras gramaticais e acabam escrevendo livros tão chatos que "nem a família os lê". Seu estilo afrontou os cânones literários da época tanto pela linguagem empregada, quanto pelos temas tratados em sua obra - traição, roubo, delação - e pelos personagens e cenários em que estes circulam - cafés imundos, prostíbulos, pensões baratas.

É bem verdade que outros autores, como Fray Mocho, Félix Lima e Last Reason (citado por Arlt com admiração, em suas Aguafuertes), também introduziam a lin- 
guagem populare a dos imigrantes em seus textos; mas restringiram-se aos artigos de costumes. Arlt vai mais além: insere-as também em seus romances.

\section{TRADUZIR ARLI, NA PRÁTICA}

Uma das dificuldades que se impõe ao tradutor de Arlt diz respeito à gíria bonaerense dos anos 20-30 (o lunfardo), fartamente utilizada pelo autor, principalmente nas suas crônicas, as Aguafuertes Porteñas. Se, por um lado, não é possível falar como nessa época, e nem se justificaria porque ninguém entenderia, por outro, não é possível usar gírias atuais, pois isso quebraria o espírito do texto, descaracterizaria o relato. Tenho procurado, na medida do possível, uma solução intermediária, inteligível para a maioria dos brasileiros e, ao mesmo tempo, levando em conta a equivalência social e lingüística de grandes centros urbanos - com a mesma imigração italiana -, optado por um registro paulistano.

Ao mesmo tempo, na tentativa de trazer para a tradução ecos de uma linguagem não tão contemporânea, tenho mantido palavras como "cinematógrafo", "edíficios de apartamentos", "vitrola", "mangos", presentes também no português. Algumas vezes os termos não são iguais nas duas línguas, mas a tradução tem obedecido o mesmo procedimento. É o caso de guita, traduzido por "prata", presente na aguafuerte "O Homem do Apuro" (4); se optasse por "grana”, soaria muito contemporâneo:

"-Nena, dame quince guitas para un paquete de cigarrillos".

“- Princesa, me dá quinze pratas para um maço de cigarros".

Outra característica marcante na escritura de Arlt é o uso de aspas em algumas palavras ou expressões. Às vezes elas aparecem junto ao lunfardo, às vezes não; no mesmo texto, a mesma palavra ora está entre aspas, ora não. É o caso, por exemplo, da expressão lunfarda "levantar a vigilância", em "Conversas de Ladrões" (5) que, no início do texto, aparece entre aspas e, no final, não mais:

“Quando um ladrão anuncia seu propósito de viver decentemente, a primeira coisa que faz é solicitar que lhe 'levantem a vigilância",.

$[\ldots]$

“O garçom se aproxima sonolento e, de repente, em diversas direções, quase grudados nas paredes, elásticos como panteras e rápidos no sumiço, os malandros se escafedem. E, de cinco deles, quatro pediram levantamento da vigilância”.

Nesta mesma aguafuerte, puxador (carrero, no original), palavra que também pertence ao lunfardo, não é colocada entre aspas. Em contrapartida, ofício, que não é lunfardo e apenas designa uma ocupação, sim; o mesmo ocorre com trabalho:

“O delegado Romayo uma vez me mostrou o caderno de um ladrão em cuja casa acabava de fazer uma limpeza. Esse ladrão, que trabalhava como puxador, era um enxadrista excelente".

$[\ldots]$

“- Efetivamente, vocês têm razão. Não é qualquer um que pode ser ladrão...

- Mas claro! É o que eu digo... Se eu quisesse me meter a escrever suas notas, não poderia, não é?... Com o 'ofício' é a mesma coisa".

\section{$[\ldots]$}

“Ah! Isso não é nada. Há 'trabalhos’ lindos... limpos... Esse do roubo da agência Nassi... Essa rapaziada promete...".

Cito somente estes casos a título de ilustração, mas a anarquia na colocação das aspas está presente em toda sua obra.
4 "El Hombre del Apuro", in Aguafuertes Porteñas, Buenos Aires, Losada, 1996, p. 126

5 "Conversaciones de Ladrones" in op. cit., pp. 135-8. 


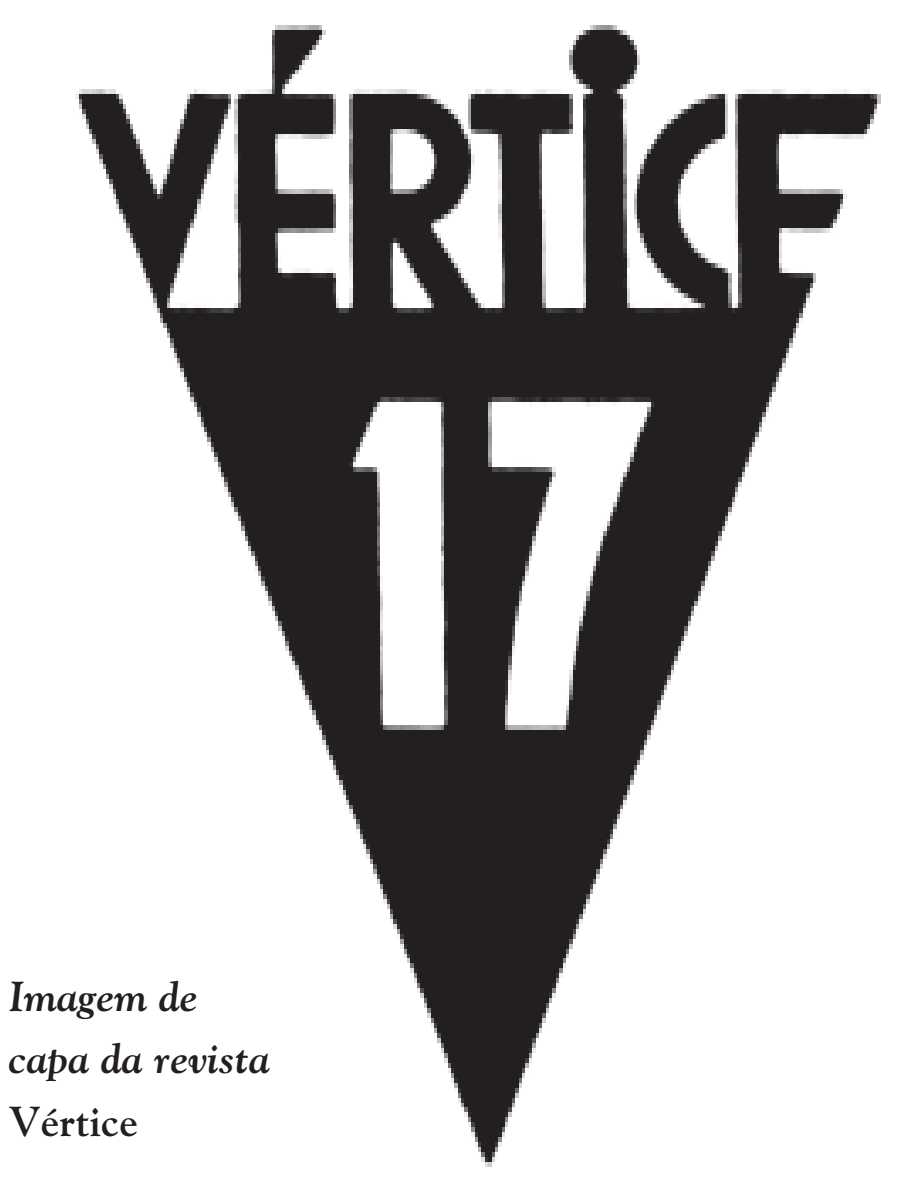

6 Paul Verdevoye, "Aproximación al Lenguaje Porteño de Roberto Arlt", in Seminario sobre Roberto Arlt. Poitiers, 1980, p. 44

7 Noemí Ulla, Identidad Rioplatense, 1930. La Escritu ra Coloquial (Borges, Arlt, Hernández, Onetti), Buenos Aires, Torres Agüero Editor 1990, p. 91

8 Roberto Arlt, Viagem Terrivel tradução, apresentação e cronologia de Maria Paula Gurge Ribeiro, São Paulo, lluminuras, 1999, p. 41
Há toda uma discussão a respeito disso, se seria um descuido do autor ou uma intervenção dos editores, na tentativa de "corrigir" o texto (fato frequiente, aliás; daí a importância de se fazer um cotejo entre as várias edições). Paul Verdevoye (6) destaca a descontinuidade na colocação das aspas e levanta algumas hipóteses: que talvez se devesse ao "acaso da inspiração, à vontade de chamar a atenção em alguns casos e, em outros não, à confusão entre palavras empregadas por todos na linguagem comum e outras de uso raro". Noemí Ulla (7) afirma que, em suas pesquisas, encontrou "lunfardismos, portenhismos ou palavras que se queriam destacar, entre aspas, de forma descontínua, nas revistas da época”. Inclino-me a acreditar então que seja muito mais uma atitude deliberada de Arlt no sentido de enfatizar o caráter irônico que quer dar a determinada palavra ou expressão, ou salientar um sentido especial no seu uso e não meramente para destacar que se trata de uma gíria ou de um vocábulo estrangeiro. Mesmo porque, como já foi dito, não há uma uniformidade na colocação das aspas. Por se tratar de uma marca forte no estilo do autor, ao traduzir, tenho mantido o mesmo procedimento. O curioso é que sempre seja preciso destacar isso no diálogo com o revisor do texto e, até mesmo, num prólogo, de forma a não parecer, aí sim, um mero descuido do tradutor.

Com exceção de $O$ Criador de Gorilas - contos africanos - e da peça África, os personagens arltianos vivem em Buenos Aires. Sendo assim, há alguns termos que são tipicamente portenhos, como "compadrito", usado para designar o sujeito vulgar, briguento, fanfarrão. Haveria, talvez, a possibilidade de traduzir por " $m a-$ landro", mas que não revela toda a riqueza do "compadrito". Além do mais, os portenhos têm também a figura do "malandrín". Por não terem um correspondente em português, tenho optado por deixálos no original, em itálico.

Faz parte do estilo de Arlt a repetição de frases e/ou palavras, às vezes ao longo do texto e, freqüentemente, dentro de um mesmo parágrafo. Se isso não representa uma "dificuldade" de tradução, no sentido de entendimento e de busca de um equivalente na língua de chegada, é uma questão a que o tradutor tem que estar atento a fim de manter o tom do relato.

Muitas vezes, a repetição se dá em relação aos advérbios terminados em "mente". Em Viagem Terrível (8), Arlt escreve, por exemplo:

"Eram onze da noite. Uma batida sacudiu a lateral da nave, estremecendo o lado esquerdo do "Blue Star" de cima a baixo. $\mathrm{Na}$ timoneira, o sino do telégrafo de ordens começou a repicar desesperadamente, enquanto o navio, estranhamente ferido, começou a girar suavemente. Subitamente produziu-se a ausência de trepidação no colosso". 
E em Os Sete Loucos (9):

"Erdosain sobressaltou-se. Tinha o cabo longo e a tira curta, e Barsut, que agora seguia seu olhar, franziu o lábio depreciativamente. Erdosain olhou sucessivamente para o homem e para o chicote e sorriu novamente. Dirigiu-se para o canto e retirou a chibata. Agora Barsut tinha colocado-se de pé e com os olhos terrivelmente fixos em Erdosain, colocava o corpo para fora da baia. As veias do seu pescoço dilataram-se extraordinariamente”.

Em “Decadência da Receita Médica",é o radical que se repete:

“Ontem, quero dizer há vinte anos, chegava da Espanha um galego, trabalhava como lavador de chão cinco anos numa farmácia, ao cabo dos cinco anos e depois de ter dado fartas mostras de fidelidade e honradez a seu patrão, este o promovia a lavador de garrafas e ajudante de laboratório, e o sujeito passava a manipular os ácidos e a preparar receitas aplicando, na ausência de seu patrão, injeções escassas, e ora opinando sobre as doenças, que em ritmo de consulta vinham exteriorizar as lavadeiras da vizinhança".

É claro que se poderia pensar em substituir alguns desses termos por outros; no entanto, não podemos nos esquecer que a escritura de Arlt, justamente, não segue o discurso erudito canônico. E a repetição é uma das formas de transgredir este cânone. Além disso, por ser algo recorrente em toda sua obra, optei por reproduzir o mesmo procedimento em português.

Ao realizar essas traduções, tenho procurado, na medida do possível, preservar em português as particularidades estilísticas de Arlt. Claro que algumas soluções são mais satisfatórias que outras e, se não fosse a existência de um prazo para a entrega do trabalho, o tradutor estaria permanentemente encontrando novas soluções para o texto, na medida em que cada leitura possibilita a produção de uma versão diferente do mesmo texto. Assim, um texto - e uma tradução - nunca é definitivo, pois, segundo Borges, "o conceito de texto definitivo não corresponde senão à religião ou ao cansaço” (10).
Os Sete Loucos \& Os lançchamas, tradução de Mario Paula Gurgel Ribeiro, São Pau o, lluminuras, 2000, p. 100

10 "Las Versiones Homéricas", in Jorge Luis Borges-Obras Com pletas, vol. I, Barcelona, Emecé, 1989 , p. 239

\section{BIBLIOGRAFIA}

ARLT, Roberto. Aguafuertes Porteñas. Buenos Aires, Losada, 1996. Aguafuertes Porteñas: Cultura y Política. Prólogo de Sylvia Saítta. Buenos Aires, Losada, 1994. . Os Sete Loucos \& Os Lança-chamas. Tradução, apresentação e cronologia de Maria Paula Gurgel Ribeiro. São Paulo, lluminuras, 2000.

. Viagem Terrível. Tradução, apresentação e cronologia de Maria Paula Gurgel Ribeiro. São Paulo, lluminuras, 1999.

BORGES, Jorge Luis. Jorge Luis Borges - Obras Completas, vol. I. Barcelona, Emecé, 1989.

ULLA, Noemí. Identidad Rioplatense, 1930. La Escritura Coloquial (Borges, Arlt, Hernández, Onetti). Buenos Aires, Torres Agüero Editor, 1990.

VERDEVOYE, Paul. "Aproximación al Lenguaje de Roberto Arlt", in Seminario sobre Roberto Arlt. Poitiers, 1980, pp.133-85. 


\section{Rumn ao Brasil em}

\section{primeira classe:}

\section{SYLVIA SAITTA}

é investigadora do Conicet e professora de Literatura Argentina na Universidade de Buenos Aires. É autora de El Escritor en el Bosque de Ladrillos. Una Biografía de Roberto Arlt

(Sudamericana) e

Regueros de Tinta. EI

Diario Crítica en la Década de 1920 (Sudamericana), que mereceu o primeiro prêmio de melhor livro argentino de história argentina da Fundación El Libro.

\section{Roberto Arlt no}

\section{Rio de Janeiro}

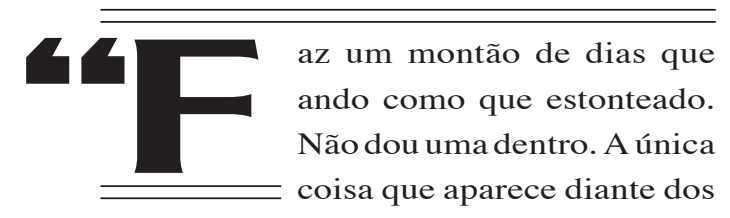

meus olhos é a passarela de um 'píccolo' navio. Eu a bordo! Caio e me levanto! Eu a bordo! 'Hoje, dio'" (1), escreve, numa água-forte portenha, o escritor e jornalista argentino Roberto Arlt quando o diretor do jornal El Mundo the confirma um giro jornalístico por vários países da América Latina. Trata-se de sua primeira viagem fora do país e Arlt está realmente ansioso, porque poderá conhecer outros costumes e outras culturas, e obter assim novos temas para escrever sua coluna cotidiana. Porque já fazia dois anos que Arlt escrevia diariamente sua coluna de "Águas-fortes 
Portenhas", uma sutil observação das mudanças urbanas, sociais e políticas de Buenos Aires da primeira metade do século XX. Irônicas, incisivas, zombeteiras, as notas de Arlt são uma intervenção pública sobre os debates estéticos e culturais do momento, uma construção de tipologias urbanas e, também, um agudo registro de suas leituras críticas sobre livros, filmes e eventos culturais. É a partir das páginas de El Mundo que Arlt olha para seu entorno e analisa o labor de seus contemporâneos, aproveitando a ductilidade de uma coluna jornalística cujo gênero varia de acordo com o humor de quem a escreve. Desse modo, as "Águas-fortes Portenhas" mudam seu formato de maneira constante e são, alternadamente (ou ao mesmo tempo), crônicas costumbristas, resenhas de livros, relatos de viagens, críticas estéticas ou análises de cabogramas.

Étalvez pela necessidade de prover seus leitores de um novo material de leitura que o diretor de El Mundo, Carlos Muzzio Sáenz Peña, toma a decisão de enviar seu “jornalista estrela" para uma viagem pela costa este da América Latina. Porque é o jornalismo massivo e comercial do começo do século que facilita que escritores assalariados como Arlt, filho de imigrantes e sem dinheiro, tenham a possibilidade de conhecer "novos céus, cidades surpreendentes, gente que nos pergunte com uma escondida admiração: 'Você é argentino? Argentino de Buenos Aires?' ", através de viagens internacionais. E, diferentemente dos escritores pertencentes à elite, Arlt, como outros jornalistas profissionais, se converterá num cronista de viagens, que responderá com sua escritura a uma demanda do jornal, que exige uma escritura rápida, em que desaparece a possibilidade de correção e, ao mesmo tempo, tira a liberdade, ao impor pautas muito precisas: uso de certo tom de linguagem coloquial, proibição de temas, brevidade e um formato determinado. Imposição de pautas, é verdade, mas também umas condições de viagem que para Arlt são novas, pois essa viagem é também o reconhecimento explícito por parte da direção de El Mundo para com suas tarefas como jornalista: Arlt viajará em primeira classe e com todos os gastos pagos.

Confirmada a viagem, Arlt promete então continuar escrevendo de cada ponto de seu percurso do mesmo modo que o fazia em Buenos Aires. Igualmente, comunica suas intenções de viajante: não tentará relacionar-se com as elites intelectuais nem com os escritores e, sim, com as pessoas do povo.

“Continuarei enviando notas. Não chorem, por favor, não! Não se emocionem. Seguirei alfinetando meus próximos e papeando com vocês. Irei ao Uruguai, a Paris da América do Sul; irei ao Rio de Janeiro, onde

\section{Arlt nos \\ bastidores de uma peça de}

teatro

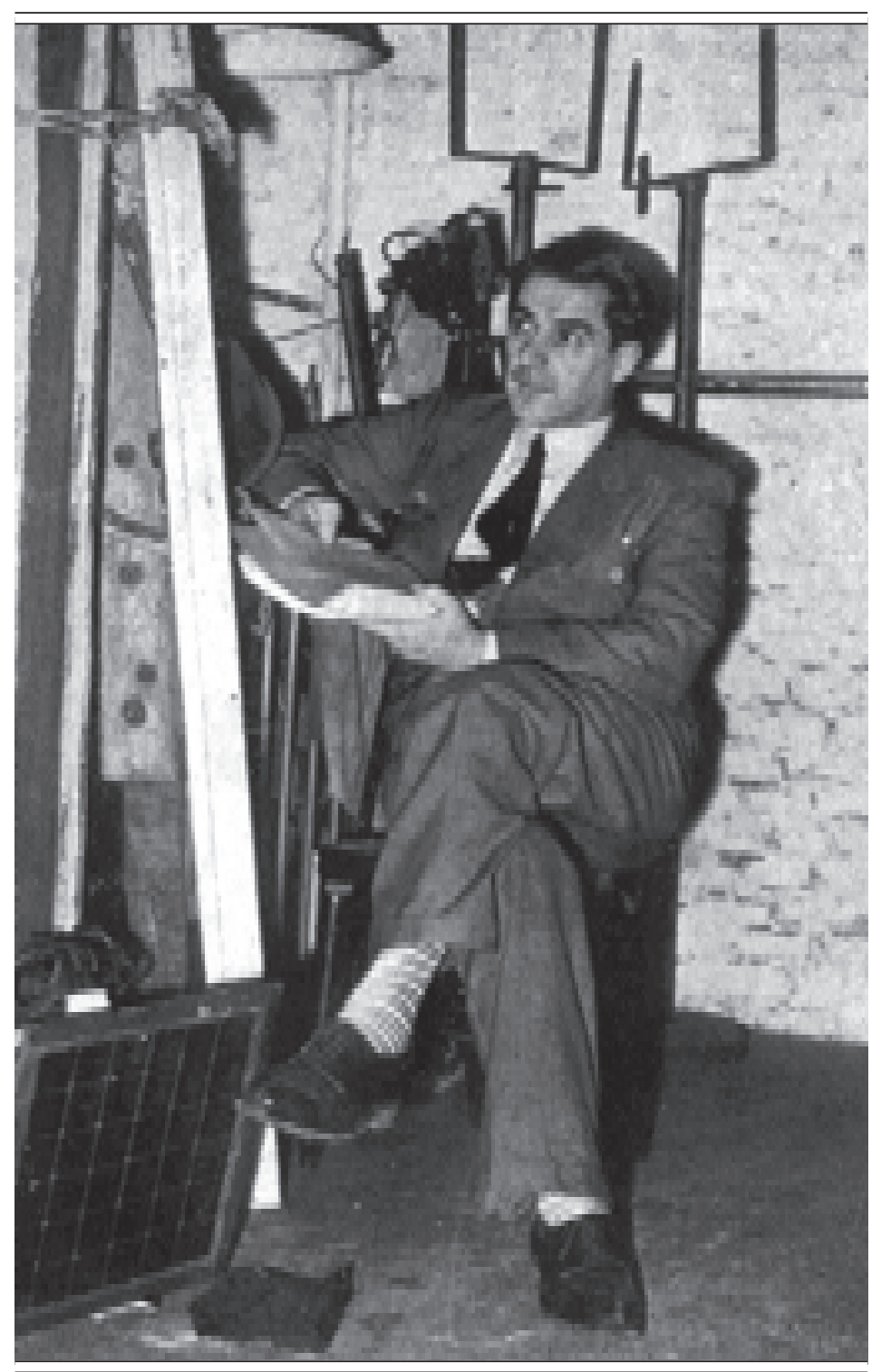


há cada 'menina' que dá calor; irei às Guianas, para visitar os presidiários franceses, a fina flor e nata do patíbulo de ultramar. [...] Penso em me misturar e conviver com as pessoas dos bas-fonds que infestam os povos de ultramar. Conhecer os rincões mais sombrios e mais desesperados das cidades que dormem sob o sol do trópico. Penso em falar para vocês das praias cariocas; das moças que falam um espanhol estupendo e um português musical. Dos negros que têm seus bairros especiais, dos argentinos fantásticos que andam fugidos pelo Brasil, dos revolucionários disfarçados. Que multidão de temas para notas nessa viagem maravilhosa que me faz escrever na 'Underwood' de tal maneira, que até a mesa treme sob a trepidação das teclas!" (2).

Então, no dia 11 de março de 1930, Arlt inicia sua primeira viagem fora do país, a bordo do transatlântico Asturias que o conduz ao Uruguai, para depois seguir viagem rumo ao Brasil, Colômbia, as Guianas, talvez Equador. O impacto de viajar na primeira classe é, para Arlt, um claro sinal de ascensão social que o arranca, talvez para sempre, de sua origem social: tomando café da manhã no suntuoso salão do Asturias se sente um milionário e olha por cima do ombro dos "pés-rapados" que viajam na terceira classe. Ilusão que se quebra quando à noite, ao entrar para jantar, os moços do salão the devolvem sua inadequação social ao apontar que um terno branco não é pertinente para a ocasião. O mesmo incidente se reitera no Darro, o barco que o conduz de Montevidéu ao Rio de Janeiro, onde o garçom, pensa Arlt, “deve ter manjado que eu, apesar de viajar de primeira, tinha cara de passageiro de terceira"

2 Idem, ibidem.

3 Idem, "Rumbo a Brasil, en Primeira Clase", in El Mundo, 31 de março de 1930

4 Idem, "Cartas que Emocionan", in ElMundo, 19 de março de 1930

5 Idem, "Ya Estamos en Río de Janeiro", in ElMundo, 2 de abril de 1930

6 Idem, "Costumbres Cariocas", in El Mundo, 3 de abril de 1930 . duas semanas. Ali, percorre ruas e bares, aloja-se em pensões baratas, assiste a festas populares, visita o porto, procura misturar-se com as pessoas que vivem em Montevidéu para transmitir aos leitores de Buenos Aires costumes alheios que facilitem "a compreensão e a aproximação de dois povos que vivem longe, a muitas horas de velocidade" (4).

Quinze dias mais tarde, parte para o Brasil no Darro, a bordo do qual sofre alguns dias de tédio e enjôos. Do convés do barco, observa, pela primeira vez, como se fosse um postal que se recorta ao longe, a cidade do Rio de Janeiro:

"No meio de um mar escuro e violáceo, cones de pedra de base rosa-lava, descampados como clareiras em certas partes, cobertos de veludo verde em outras, e uma palmeira na ponta. Bandos de pombas de mar revoam em volta. Um semicírculo de montanhas, que parecem espectrais, leves como alumínio azul, cristadas delicadamente por um bordado verde. A água ondula oleosidades da cor do salgueiro; em outras, junto aos penhascos rosas, tem reflexos de vinho aguado. Algumas nuvens como véus cor de laranja envolvem uma serra corcunda: o Corcovado. E mais longe, cúpulas de porcelana celeste, dados vermelhos, cubos brancos: Rio de Janeiro!"' (5).

Já instalado na cidade, vincula-se aos jornalistas da redação de OJornal, pois será na redação desse jornal onde Arlt escreverá suas "Notas de Viagem" para enviar a Buenos Aires. Como em Montevidéu, Arlt percorre as ruas cariocas, visita as igrejas antigas e os monumentos, mete-se em botecos e bairros pobres, e tenta apreender a psicologia de um povo tão diferente do rio-platense. A primeira coisa que o surpreende é a honestidade do povo carioca: "Defendo para sempre o Rio de Janeiro" - afirma Arlt -, "eu diria: uma cidade de gente decente. Uma cidade de gente bem nascida" (6). Decência que descobre na possibilidade que as mulheres têm de andar sozinhas pelas ruas sem que os homens as incomodem; honestidade nos costumes da cidade: 
“Escrevo sob uma estranha impressão: não saber se estou bem acordado. Circulo pelas ruas e não encontro mendigos; vou por bairros aparentemente facinorosos e onde olho só acho isto: respeito pelo próximo. Sento num café. Um desconhecido se aproxima, me pede uma cadeira desocupada e em seguida, tira o chapéu. Entro em outro café. Uma moça sozinha bebe seu refresco de chocolate e ninguém se preocupa com ela. Eu sou o único que a olha com insistência; ou seja, sou o único mal-educado que há ali" (7).

Além de percorrer as ruas, visitar monumentos e pontos turísticos, Arlt dedica muitas horas para conversar com seus colegas jornalistas de $O$ Jornal e Jornal da Noite sobre os costumes do lugar. O que chama sua atenção, principalmente, é a passividade política e sindical que observa no operário brasileiro ao compará-lo com o operário argentino, pois descobre com certa surpresa que, diferentemente do operário brasileiro, o operário argentino é discutidor porque entende de questões proletárias, faz greves, estuda, defende seus direitos sindicais e manda seus filhos para a escola para que ocupem uma posição social superior à sua (8). Arlt atribui as causas dessa diferença à ausência de instituições culturais nos bairros proletários do Rio de Janeiro: “É preciso convencer-se: Buenos Aires é única na América do Sul. Única [...] Lá, no mais ínfimo bairro operário você encontra um centro cultural, onde, com uma incompetência assombrosa, discutem-se as coisas mais transcendentais. [...] Qualquer operário nosso, pedreiro, carpinteiro, portuário, tem noções, e algumas bem sólidas, do que é o corporativismo, centros de luta social, etc. Lêem romances, sociologia, história” (9).

A viagem, portanto, transforma-se numa condição de possibilidade para ver, de fora do país, e com a perspectiva que a distância ocasiona, a situação da Argentina. E Arlt, que sempre foi muito crítico de seu país, de longe, pode sentir-se orgulhoso: "É preciso viajar para perceber certas coisas. As boas e as ruins. Teatro, jornais, romances, contos, revistas, estão formando, em nosso país, um povo que faz com que a gente, de longe, sinta-se orgulhoso de ser argentino" (10).

Interessado que está na situação do Brasil, à medida que sua viagem avança, Arlt abandona sua pose de viajante e de correspondente estrangeiroe tenta captar um temperamento tão diferente do argentino. Por isso, abomina os monumentos, desdenha as excursões pensadas para os turistas e se nega a contemplar tanto a paisagem natural como os circuitos culturais:

"Estátuas, igrejas antigas e todas as tranqueiras do outro século me deixam perfeitamente indiferente. Não me interessam. Acho que não interessa a nenhum argentino. Entediam, sejamos sinceros. Para nós, que temos os olhos acostumados à linha dos automóveis, que diabos pode nos dizer um arco de pedra ou um abside! Sejamos sinceros. As igrejas antigas não me chamam a atenção. As casas rançosas do século passado tampouco. [...] A paisagem sem homens acaba comigo. As cidades sem problemas, sem afãs e os homens sem um assunto psicológico, sem preocupações, me abatem. [...] O antigo, entre pessoas antigas, está em seu lugar; entre pessoas modernas, é de um ridículo! A paisagem acaba comigo. Não olho as montanhas nem de brincadeira. O que fazemos com a montanha? Descrevê-la? Montanhas há em toda parte. Os países não valem por suas montanhas" (11).

Escolhe, em troca, submergir entre a multidão na rua, assistir às festividades populares, como a Festa da Abolição da Escravidão, e aprender o português, em cujas palavras encontra ressonâncias da língua da rua que se fala em Buenos Aires, e ao que considera - sobretudo na boca de uma mulher - um idioma profundamente doce e insinuante: “é preciso ver uma minina! É a coisa mais deliciosa que se possa conceber, é uma fala feita para boca de mulher" (12).

No entanto, a viagem se interrompe repentinamente no dia 14 de maio de 1930 , quando Arlt recebe dois telegramas, um de seus companheiros e do diretor do jornal $E l$

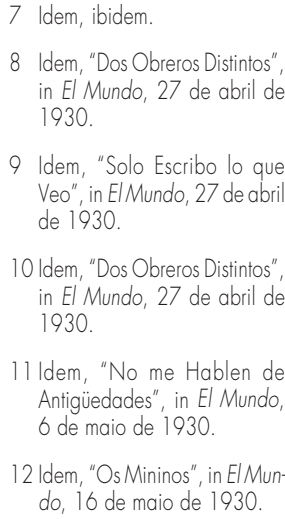

11 Idem, "No me Hablen de Antigüedades", in El Mundo, 6 de maio de 1930

12 ldem, "Os Mininos", in ElMun do, 16 de maio de 1930 
Mundo felicitando-o porque recebeu o terceiro prêmio, de dois mil pesos, no Concurso Municipal de Literatura por seu romance Os Sete Loucos; outro, da empresa Nyrba, oferecendo-lhe uma passagem para ir do Rio de Janeiro a Buenos Aires em hidroavião. E, no dia 29 de maio, Arlt embarca no hidroavião, depois de uma saída várias vezes postergada: primeiro porque não tinha os papéis em ordem, depois porque lhe faltava o visto de seu passapor- te, depois por causa de um temporal no Mar do Caribe... Desse modo, a viagem dura menos do que o pensado e em apenas dois meses Arlt está de volta à Argentina. Em que pese esta brusca interrupção, a lembrança de sua passagem pelo Rio de Janeiro será duradoura nas notas jornalísticas que Arlt escreve em seu regresso a Buenos Aires porque nelas recordará muitas de suas experiências de viagem e as inesquecíveis paisagens cariocas.

\section{BIBLIOGRAFIA}

AAVV, Conducta, no 21, julho-agosto de 1942.

AAVV, Contorno, no 2, maio de 1954.

AAVV, Cuadernos Hispanoamericanos, Los complementarios, ㄲo 11, julho de 1993.

AAVV, El Juguete Rabioso, ano 1, no1, novembro de 1990.

BORRÉ, Omar. Arlt y la Crítica (1926-1990). Buenos Aires, América Libre, 1996.

JITRIK, Noé. "La Presencia y Vigencia de Roberto Arlt”, in Roberto Arlt. Antología. México, Siglo XXI, 1980.

LARRA, Raúl. Roberto Arlt, el Torturado. Buenos aires, Ceal, 1982.

ONETTI, Juan Carlos. "Semblanza de un Genio Rioplatense", in Macedonio no 11, setembro de 1971.

PIGLIA, Ricardo. "Roberto Arlt, una Crítica de la Economía Literária", in Los Libros, março de 1973.

REST, Jaime. "Roberto Arlt y el Descubrimiento de la Ciudad", in El Cuarto en el Recoveco. Buenos Aires, Ceal, 1982. SAÍTTA, Sylvia. El Escritor en el Bosque de Ladrillos. Una Biografía de Roberto Arlt. Buenos Aires, Sudamericana, 2000.

SARLO, Beatriz. "Guerra y Conspiración de Saberes", in Una Modernidad Periférica: Buenos Aires 1920 y 1930. Buenos Aires, Nueva Visión, 1988.

. "Arlt: la Técnica em la Ciudad", in la Imaginación Técnica. Sueños Modernos de la Cultura Argentina.

Buenos Aires, Nueva Visión, 1992.

VIÑAS, David. "Arlt: Humillar y Seducir", in Marcha, Montevidéu, no 1.298, abril de 1966. 
nacional. Assim, segue para o Uruguai, Brasil, Espanha, África e sua coluna passa a se chamar Aguafuertes Uruguayas, Aguafuertes Gallegas...

Paralelamente ao trabalho jornalístico, Arlt publica contos nas revistas Don Goyo, Mundo Argentino, El Hogar, e escreve mais três romances: Os Sete Loucos (1929), Os Lança-chamas (1931) (1) e El Amor Brujo (1932).

Em 1933, publica o volume de contos El Jorobadito (2) e uma seleção das Aguafuertes Porteñas. Seu segundo volume de contos, El Criador de Gorilas, é publicado em 1941.

Os últimos dez anos de vida de Arlt foram dedicados ao teatro - sem, no entanto, abandonar sua coluna de crônicas. Escreveu cerca de treze peças, entre as quais 300 Millones, Saverio el Cruel e Pruebade Amor.

Cardíaco, Roberto Arlt morreu aos 42 anos, no dia 26 de julho de 1942, ao lado de sua segunda esposa, Elisabeth Shine. Foi cremado, e suas cinzas espalhadas na região do Tigre, delta do Rio Paraná.

Apesar de uma produção literária extensa, Arlt concedeu poucas entrevistas. Decidi, então, elaborar uma entrevista com ele, entremeando vários de seus textos, extraídos de suas crônicas. A tradução é minha. Abaixo, Arlt por Arlt.

Editados pela lluminuras (2000), com tradução de Maria Paula Gurgel Ribeiro.

2 No Brasil, saiu pela lluminuras (1996), sob o título de As Feras, com tradução de Sergio Molina.
Não disponho, como outros escritores, de rendas, tempo ou sedativos empregos públicos. Ganhar a vida escrevendo é penoso e duro.

O jornal El Mundo começou a circular em Buenos Aires em maio de 1928. A partir de quando o senhor começou a escrever nele como articulista?

Com o primeiro número de El Mundo apareceu minha primeira crônica. Confesso com toda ingenuidade: estou encantado. Se tivessem me dito que eu iria escrever tanto e por tanto tempo, não teria acreditado.

Mas é preciso que, antes de falar de mim, fale do diretor deste jornal; e não para adulálo, porque eu, por princípio, por costume e até por vício, jamais adulo ninguém e, sim, para que meus leitores possam apreciar o que significa um diretor desta qualidade, da qualidade que vou explicar em seguida. Muzio Sáenz Peña, coisa que nenhum diretor de jornal faz, me deu plena liberdade para escrever. Issoé tudo, e muito para quem entende alguma coisa de jornalismo. Liberdade, liberdade de denunciar as bobagens; liberdade de atacar a injustiça; liberdade do dizer, de ser o que se é, sem restrições, sem dissimulação

Todos os dias do ano, você pode encontrar o diretor lendo minha nota entre meia-noite e uma da manhã. É fatal. Lê devagar, colocando os pontos e vírgulas que eu esqueci, os " $h$ " que me confundiram, os "c" e os "s" transpostos do jeito mais fantástico. Quase sempre, da nota não muda nada mais que um adjetivo. Outras vezes, corrige um pensamento mal expresso.

Mas o senhor, durante todos esses anos, em nenhum momento sofreu algum tipo de controle por parte da direção do jornal?

Estou proibido de me meter em política. Ordem superior. Além disso, o diretor me diz que se eu continuar a tratar os políticos como ladrõezinhos, vão me matar; e ele quer me conservar com vida para eu continuar produzindo notas per secula seculorum. 
Freqüientemente dizem que o senhor escreve mal, e empregando muita gíria. O senhor concorda? O que tem a comentar a respeito?

É, dizem que escrevo mal. É possível. Escrevi sempre em redações estrepitosas e acossado pela obrigação da coluna jornalística. De qualquer maneira, eu não teria dificuldade em citar numerosas pessoas que escrevem bem e que são lidas unicamente pelos corretos membros de suas famílias.

Escrevo num “idioma” que não é propriamente o castelhano e sim o portenho. Sigo toda uma tradição: Fray Mocho, Félix Lima, Last Reason... Este léxico, que eu chamo de idioma, primará em nossa literatura apesar da indignação dos puristas, a quem ninguém lerá. Eu tenho essa fraqueza: a de acreditar que o idioma das nossas ruas, o idioma em que conversamos no café, no escritório, em nosso trato íntimo, é o verdadeiro. Acredite. Nenhum escritor sincero pode desonrar-se nem se rebaixa por tratar temas populares e com o léxico do povo. O que hoje é caló amanhã se transforma em idioma oficializado.
E nosso caló é o produto do italiano aclimatado; trata-se de palavras frescas e sonoras nos lábios negros de mascar tabaco, dos robustos imigrantes que se estabeleceram em Boca e Barracas. Além disso, há algo mais importante que o idioma, e são as coisas que se dizem. Dessa forma, chegaremos à formação de um idioma sonoro, flexível, flamante, compreensível para todos, vivo, nervoso, colorido por estranhos matizes e que substituirá um rígido idioma que não corresponde à nossa psicologia. Os futuros acadêmicos argentinos me agradecerão e eu terei tido o prazer de morrer sabendo que trezentos e sessenta e um anos depois me levantarão uma estátua.

Em toda sua obra, além de tratar de tipos que habitam Buenos Aires, as ruas também são personagens. Há ruas mais canalhas, outras encantadoras...

É verdade. Esmeralda, Talcahuano, Rivadavia, Alsina, a rua mais lúgubre de Buenos Aires... Corrientes, a rua mais linda do mundo. Rua portenha de todo coração. Linda e brava rua. Rua do galanteio

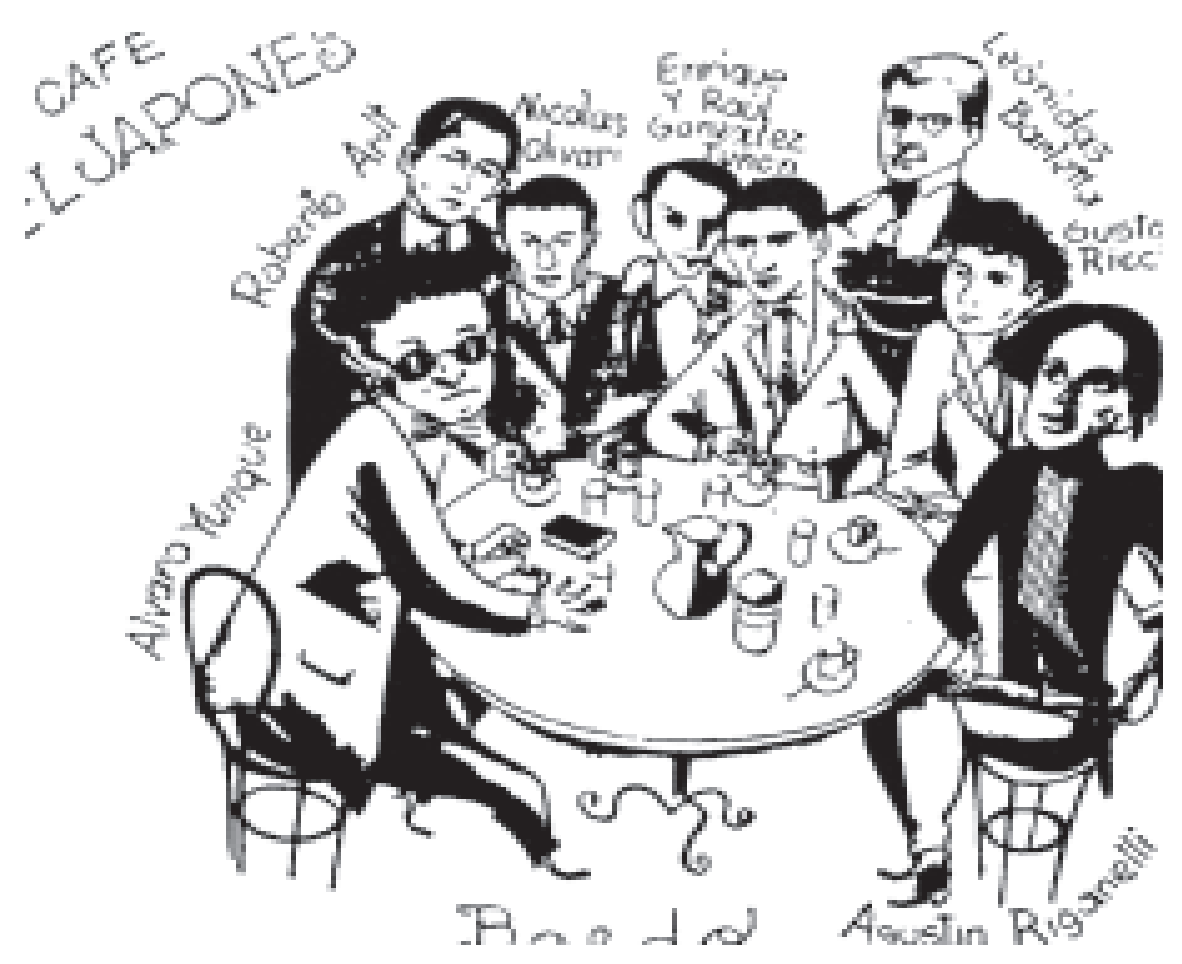

Arlt entre amigos, numa caricatura 
organizado, dos desocupados com dinheiro, dos sonhadores, dos que têm uma "condicional" e se cuidam feito a mãe cuida da criança.

Aprendi que a escola mais útil para o entendimento é a escola da rua, escola amarga, que deixa um acre sabor na boca, um prazer agridoce e que ensina tudo aquilo que os livros não dizem jamais.

Que autores mais o influenciaram?

Meus mestres espirituais, meus mestres de humorismo, de sinceridade, de alegria verdadeira, são todos os dias Dickens - um dos maiores romancistas que a humanidade já conheceu e conhecerá - Eça de Queiroz, Quevedo, Mateo Alemán,
Dostoiévski - o Dostoiévski de Stepamchikovo e seus Habitantes Cervantes e o próprio Anatole France. Com eles, meus amigos invisíveis, aprendi a sorrir; e isso é muito.

Por fim, para Arlt, o que é o homem? O homem é um animal extraordinário. Tem possibilidades fantásticas. Indubitavelmente, quando tem condições - até agora temos passado junto às coisas mais belas da terra com uma espécie de indiferença de proto-homens -, encontra tangentes inesperadas para transformar-se sempre em melhor e melhor. E talvez a verdadeira vida seja isso: constante superação de si mesmo.

\section{BIBLIOGRAFIA}

ARLT, Roberto. Aguafuertes Porteñas. Buenos Aires, Losada, 1996 ("El 'Furbo" ", p. 38; "El Origen de Algunas Palabras de Nuestro Léxico Popular", p. 40; "La Inutilidad de los Libros", p. 183; "Motivos de la Gimnasia Sueca", pp. 69-70; "La Madre en la Vida y en la Novela", p. 149; "La Calle Corrientes no Cambiará con el Ensanche", pp. 149-51; “Una Excusa: el Hombre del Trombón”, p. 72).

. Aguafuertes Porteñas: Cultura y Política. Prólogo de Sylvia Saítta. Buenos Aires, Losada, 1994 ("La

Crónica no 231", pp. 27-30; “¿Cómo Quieren que Yo les Escriba?", pp. 31, 32 e 33; "El Derecho de Alacranear”, p. 38; "Para ser Periodista", p. 43).

. Nuevas Aguafuertes Porteñas. Estudo preliminar de Pedro G. Orgambide. Buenos Aires, Hachette,

1960 ("La Censura", pp. 247 e 248).

. Os Sete Loucos \& Os Lança-chamas. Tradução, apresentação e cronologia de Maria Paula Gurgel Ribeiro. São Paulo, lluminuras, 2000 ("Palavras do Autor", p. 193).

SAÍTTA, Sylvia. El Escritor en el Bosque de Ladrillos. Buenos Aires, Sudamericana, 2000, p. 60 (recompilação de um trecho de "Contestando a los Electores" publicado originalmente em El Mundo, 26 de outubro de 1930). 


\section{Dois contos}

\section{de Roberto Arlt}

Trad. Maria Paula Gurgel Ribeiro
Conto publicado originalmente na revista Don Goyo em 18/5/1926 e recompilado em El Resorte Secreto y Otras Páginas (Buenos Aires, Simurg, 1996, pp. 92-4).

\section{A UM POETA BEM VESTIDO}

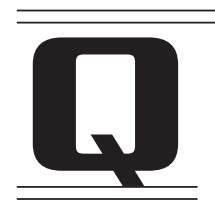

ue grande, que encantador, que genial que você é, dentro de teu sobretudo de autêntico pano inglês!

Eu te falo com a deliciosa admiração de minhas algibeiras órfãs de dinheiro... Que grande, que encantador, que genial que você é! Nesta cidade de Buenos Aires, você parece o deus Apolo que passeia incógnito.

A pontiaguda elegância de seus sapatos me faz compreender que unicamente os poetas bem vestidos são de uma substância diferente da dos vates maltrapilhos, com a barra da calça esfiapada e o tecido do terno, frágil como casca de cebola.

Que grande... que encantador... que genial que você é!

Refletindo sobre todas as prendas com que te adornas, não encontro palavras para exaltar tua prudência na eleição das roupas, tua sabedoria em usá-las de forma que se compreenda que teu espírito seleto está em harmonia com as galas que usa. Um exemplo: tuas gravatas.
A maioria das pessoas compra suas gravatas com a indiferença com que negociaria uma corda para se enforcar. Em compensação, em você, vê-se que a fantasia que demonstra em teus versos transcende as gravatas que te pertencem. Eu diria que os escrúpulos que magnificam teus poemas resplandecem nos tornassóis de tuas "gravatonas" duras feito pedra e na alegria fácil dessas outras, que parecem fabricadas com o plaid de um escocês. Até tuas camisas, tuas camisas de seda, têm o delicioso frufru que fazem as anáguas das marquesas ao passar pelas alcovas de teus versos!

E o corte do seu terno? Para beijar-lhe as mãos e chamar-lhe de meu rei, gostaria de conhecer o alfaiate que te confeccionou o terno. Que habilidade a sua, que trigonometria de sua tesoura! Tanto é, que eu concebo esse teu artesão usando um teodolito para tomar-lhe as medidas. Sim: só consultando os astros e utilizando um teodolito, pode ter traçado com tal perfeição as cotangentes de tua elegância.

De outra maneira não se explicariam as ombreiras do paletó, que têm um declive suave como a asa de um cisne. Ea caída das lapelas? Um novo Newton não precisaria da queda da maçã para descobrir a lei da gravidade. Só de olhá-las, seria suficiente. E o garbo da cintura? E a severidade com que te ajusta o pano dos quadris? Viva Deus, que há de recomendar-me a esse engenheiro do dedal!

Não digo nada da rigidez de tuas calças, nem da interessante palidez de tuas meias bordadas, porque as pessoas achariam que 
estou te adulando, mas em meu interior, acredite, há uma voz que diz constantemente:

"Que grande... que encantador... que genial que você é!"

No entanto..., o prodígio... o que torna altissonante tua figura, o que concede a teus poemas uma grandeza dantesca, não são suas gravatas nem teu terno..., não: é teu sobretudo, esse amplo sobretudo cinza, autêntico pano inglês... e que em certas oportunidades te dignas a usar, e até permite - Deus sempre levará em conta esse rasgo - que o toquemos e provemos, nós, os esfomeados, os grosseiros, os inspirados, quando jogamos o absurdo jogo do poeta rico.

Teu sobretudo!

Assim como esse Pai da Igreja chamado Tertuliano escreveu um volume sobre $\mathrm{O}$ Manto, o modesto manto romano que os pedantes chamam "pallium”, eu quero escrever o tratado de O Sobretudo... de teu sobretudo.

Tua figura, embrulhada nele, faz-se eloquiente, patrícia, grave. Até os diretores de revistas, gente maldosa e traquinas com os vates, se enternecem na presença de teu sobretudo. Eles, que riem de Virgílio, a quem você se assemelha, quando te vêem comparecer com teu sobretudo, acreditam que você é o cisne de Mântua, como dizem os bobos que estudaram latim e, amainando suas gozações, te recebem, te acolhem, publicam o que lhes leva e te pagam... te pagam... Teu sobretudo!

Eu ouvi uma mística dizer, certa vez que você passava, que, com um sobretudo assim, Cristo viria novamente à terra.

Teu sobretudo!

Te dá tal aspecto de homem abastado e sisudo, que eu, mais de uma vez, vi os burgueses pararem no meio da calçada com suas crianças, para gozar do prazer de te olhar.

Até parece que você tinha pinta de "salvador da pátria".

2 Crônica publicada originalmente no jornal El Mundo em $21 / 1 / 1930$ e compilada pelo próprio autor no volum Aguafuertes Porteñas, publicado pela editora Vitoria, em 1933. A fonte desta traducãa foi a edição Losada, de 1996 pp. 135-8. veis no sobretudo, que te concede um aspecto augusto, vertem lágrimas.

Que grande..., que encantador..., que genial que você é!

Assim como Mercúrio adormeceu com seus cantos sutis o terrível Argos, assim você, com teu sobretudo, apaziguas os críticos, os escorpiões e os editores. Todos se descadeiram em te servir...

\section{CONVERSAS DE LADRÕES}

Às vezes, quando estou entediado e me lembro de que num café que conheço se reúnem alguns senhores que trabalham como ladrões, me encaminho para ali para escutar histórias interessantes.

Porque não há gente mais aficionada em histórias do que os ladrões.

Será que esse hábito provém da prisão? Como é lógico, eu nunca pedi determinadas informações a essa gente que sabe que escrevo e que não tenho nada a ver com a polícia. Além do mais, o ladrão não gosta de ser perguntado. Basta você lhe perguntar alguma coisa, fecha a cara como se se encontrasse diante de um auxiliar e no escritório de uma delegacia.

Eu não sei se muitos de vocês leram Contos de um sonhador, de Lord Dunsany. Lord Dunsany tem, entre seus relatos maravilhosos, um que me parece que vem a calhar. É a história de um grupo de vagabundos. Cada um deles conta uma aventura. Todos choram, menos o narrador. Terminado o relato, o narrador incorpora-se ao círculo de ouvintes; outro, por sua vez, retoma um novo romance que faz chorar também o recente narrador.

Bom, o caso é que entre os ladrões acontece a mesma coisa. É sempre à uma ou às duas da madrugada. Quando, por A ou por $\mathrm{B}$, não têm que trabalhar, é quase sempre num período da vida em que anunciam um firme propósito de viver decentemente. Daí acontece uma coisa estranha. Quando um ladrão anuncia seu propósito de viver decentemente, a primeira coisa que faz é solicitar que lhe "levantem a vigilância". 
Nesse intervalo de férias, prepara o plano de um "golpe" surpreendente. A polícia sabe disso, mas a polícia precisa da existência do ladrão; precisa que, a cada ano, se lance uma nova fornada de ladrões sobre a cidade porque, senão, sua existência não se justificaria.

Em tal intervalo, o ladrão freqüenta o café. Reúne-se com outros amigos. É depois do jantar. Joga cartas, dados ou dominó. Alguns também jogam xadrez.

O delegado Romayo uma vez me mostrou o caderno de um ladrão em cuja casa acabava de fazer uma limpeza. Esse ladrão, que trabalhava como puxador, era um enxadrista excelente. Tinha anotados nomes de mestres e soluções de problemas enxadrísticos resolvidos por ele. Esse assaltante falava de Bogoljuboff e Alekhine com a mesma familiaridade com que um "turfista" falava de pedigrees, aprontos e performances.

À uma ou às duas da madrugada, quando já se encheram de jogar, quando alguns foram embora e outros acabam de chegar, faz-se em volta de qualquer mesa um círculo austero, tedioso, canalha. Círculo silencioso, do qual, de repente, escapam estas palavras:

- Sabem? Em Olavarría agarraram o Japonês.

Todos os malandros levantaram a cabeça. Um disse:

- O Japonês! Lembra quando eu andei por Bahía Blanca? Barbarizamos junto com o Japonês.

Agora o tédio dissolveu-se nos olhos, e os cangotes se enrijecem à espera de uma história. Poderia dizer-se que aquele que falou estava esperando que qualquer frase dita por outro servisse de trampolim, para lançar histórias que armazena.

- O Japonês. Não era ele que esteve em...? Dizem que esteve no assalto com a Velha...

Um olha para mim.

— É a “maior enganação”. Imagina se vai estar no assalto!

- É verdade que se o senhor encontra o Japonês de noite...

- Olha, meu chapa. O Japonês é feito uma menina, de tão educado.

Explode uma gargalhada, e outro:

- Deve ser feito uma menina, mas te dou de presente. De onde você tirou isso de que é feito uma menina?

- Quando eu tinha dezesseis anos estive preso com ele, em Mercedes... Era feito uma menina, estou te dizendo. Vinham as senhoras de caridade, olhavam para nós e diziam: "Mas como é possível que esses garotos sejam ladrões!” E me lembro que eu respondia: "Não senhorita, é um erro da polícia. Nós somos de boa família”. E o Japonês dizia: "Eu quero ir com minha mamãezinha”... Estou te dizendo: é feito uma menina!

Explodem as risadas, e um ladrão me

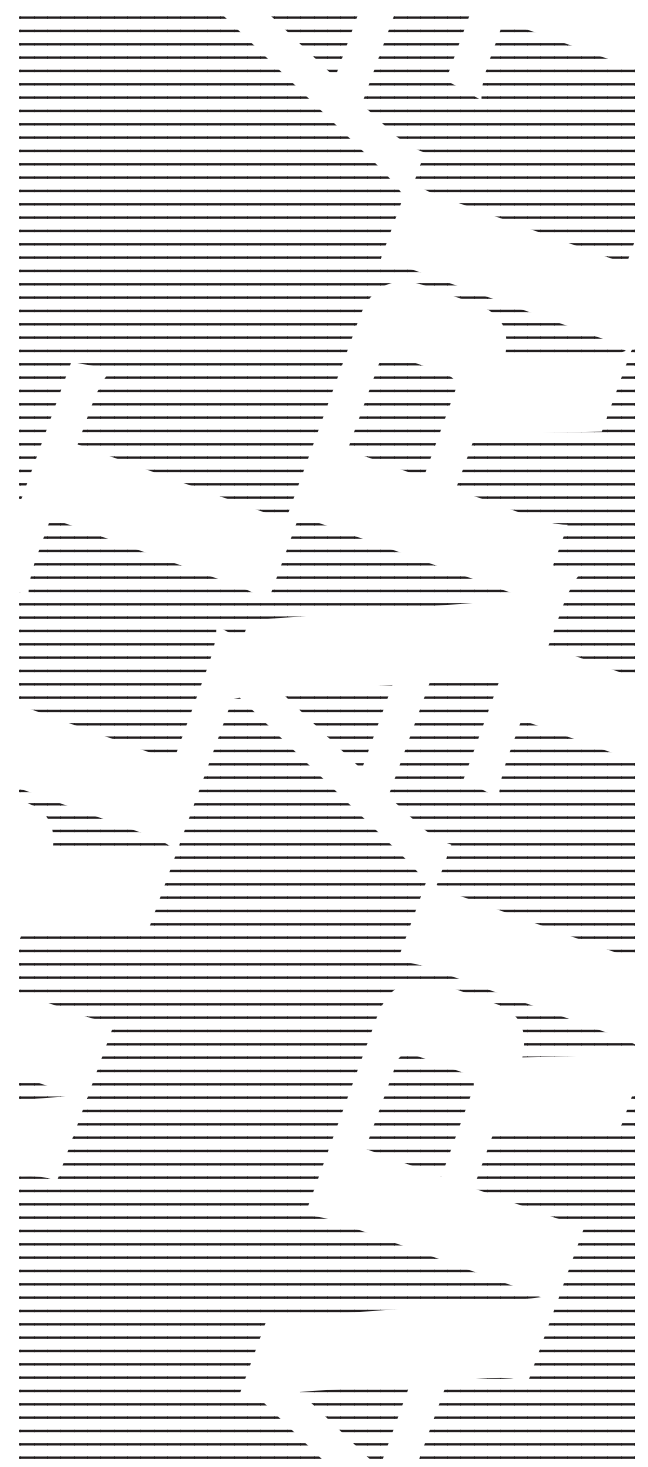


pega pelo braço e me diz:

- Mas não acredite nele. O senhor está vendo a fuça que eu tenho, não? Bom. Eu sou um anjinho perto do Japonês. Mas veja: um "bocó" encontra o Japonês e só de vêlo, se manda como se visse a morte. E esse aí diz que era uma menina... Eu me lembro de uma loja de queijos que assaltamos com o Japonês... Levamos uns duzentos queijos num carrinho. O trabalho para vendêlos!... E o cheiro! Seguia-se a pista só pelo nosso cheiro...

Outro:

- Do jeito que está agora o ofício, está arruinado. Se encheu de pobres-diabos que dão com a língua nos dentes. Qualquer tonto quer ser ladrão.

Eu olho, reflito e digo:

- Efetivamente, vocês têm razão; não é qualquer um que pode ser ladrão...

- Mas claro! É o que eu digo... Se eu quisesse me meter a escrever suas notas, não poderia, não é?... E com o "ofício" é a mesma coisa. Vamos ver; me diz, como o senhor faria para roubar agora o patrão que está no caixa?... Olha que a gaveta está aberta...

- Não sei...
- Mas meu amigo, não diga isso! Veja; aproxima-se do balcão e diz ao patrão: "Me passe essa garrafa de vermute". O patrão vira o corpo para esse lado da prateleira. Assim que o homem está para retirar a garrafa, o senhor diz: "Não, essa não; a que está mais para cima”. Como o trompa está de costas, o senhor pode limpar o caixa... Percebe?...-Eu me admiro convencionalmente, e o outro continua: - Ah! Isso não é nada. Há "trabalhos" lindos... limpos... Esse do roubo da agência Nassi... Essa rapaziada promete..

- E o Japonês? Eu me lembro: vínhamos uma vez no trem... Íamos para Santa Rosa...

Três da madrugada. Quatro. Um círculo de cabeças... um narrador. Digam o que disserem, as histórias de ladrões são magníficas; as histórias da prisão... Cinco da madrugada. Todos olham o relógio, sobressaltados. O garçom se aproxima sonolento e, de repente, em diversas direções, quase grudados nas paredes, elásticos como panteras e rápidos no sumiço, os malandros se escafedem. E de cinco deles, quatro pediram levantamento da vigilância. Para melhor roubar!... 